\title{
Sorghum Downy Mildew of Maize - A Review
}

\author{
S. Arulselvi ${ }^{1 *}$, B. Selvi ${ }^{2}$ and M. Pandiyan ${ }^{1}$ \\ ${ }^{1}$ Agricultural College and Research Institute, Tamil Nadu Agricultural University, \\ Eachangkottai, Thanjavur - 614 902, Tamil Nadu, India \\ ${ }^{2}$ Department of Millets, Tamil Nadu Agricultural University, Coimbatore - 641003 , \\ Tamil Nadu, India \\ *Corresponding author
}

\section{A B S T R A C T}

\begin{tabular}{|l|}
\hline Ke y w or d s \\
Sorghum downy, \\
Mildew, Maize
\end{tabular}

Introduction

Maize or corn (Zea mays L.) is an important cereal crop of the world after wheat and rice. It is an annual, herbaceous, monoecious and protandrous plant (Dhillon, 1998).

It probably originated in Mexico and evolved from teosinte (Zea mexicana) (de Wet and Harlan, 1972). Being a C4 plant, it is physiologically more efficient and has higher grain yield and wider adaptation over a range of environmental conditions (Dowswell et al., 1996). Maize has a wider range of uses than any other cereals as animal feed, human food and for hundreds of industrial purposes (Dhillon, 1998).
The average area under this crop of the world is $177.37 \mathrm{~m}$ ha with a world average production and productivity is around 872.06 million tonnes and 4.9 tonnes per hectare respectively (FAO, 2012). After the discovery of America by Europeans in Columbus' time its cultivation spread rapidly to all suitable parts of the world. The important maize growing countries are the USA, China, Brazil, Mexico, India, Philippines, South Africa and Indonesia. Maize is a relatively new crop to Asia, compared with other important cereals. This crop was introduced in the sixteenth century by European traders to Asia as an ornamental garden plant and did not become agriculturally important until 200 or 300 years later (Moore and Renfro, 1971). 
In India, maize is grown in an area of 9.43 million hectares and the annual production is about 24.35 million tonnes with a productivity of 2.58 tonnes per hectare (Agricultural Statistics at a Glance, 2014). In Tamil Nadu, maize occupies 3.21 lakh hectares with an average production and productivity of 2.64 lakh tonnes and $8224 \mathrm{~kg}$ per hectare respectively (Department of EconoFmics and Statistics, Chennai, 2014). It is expected to increase in future to meet the growing demands of poultry and other animals feed industry, industrial utilization and human consumption. The demand for maize is increasing every year. According to recent study (The Hindu Survey of Indian Agriculture, 2000), in 2015 the domestic demand for maize will be about 12 million tonnes and in 2030 it will be 13.5 million tonnes and for Tamil Nadu state it is about ten to twelve lakh tonnes. The commercial exploitation of single cross hybrids in maize, initially suggested by Shull (1909), is emerging again because of their uniformity in plant ear characters than other types of hybrids and high yield potential. Frey (1971) reported that yield increases in the USA after 1957 were mainly due to the wide cultivation of single cross hybrids. Due to yield advantage, hybrids dominate in maize cultivation over varieties. Hence, high yielding single cross hybrids are the need to meet the growing demand. To meet this demand it is necessary to increase the productivity of maize. One of the major factors limiting productivity in maize is the increasing incidence of pest and diseases. Of these, sorghum downy mildew (SDM) caused by Peronosclerospora sorghi (Weston and Uppal) C.G. Shaw is the most prevalent downy mildew in the tropical and subtropical areas of the world (Frederiksen et al., 1969; Pupipat, 1975; Frederiksen and Renfro, 1977 and Williams, 1984).

Though the disease can be controlled by cultural practices such as eradication of infected plants, deep ploughing and adjusting time of planting and by systemic fungicide, Metalaxyl either through seed treatment (Odvody and Frederiksen, 1984a) or foliar application (Odvody and Frederiksen, 1984b), their effectiveness on disease incidence is variable and in most cases, offer incomplete control. Moreover the economic costs of chemical control in maize production have been a barrier. Considering the cost of chemicals and the emergence of chemical resistance in the downy mildew pathogens (Raymundo, 2000) use of host plant resistance seems to be the most effective, economical and environmentally safe way of controlling SDM disease in maize (Rathore and Jain, 2000). The genetic information relating to host resistance is vital for making breeding decisions.

\section{Downy mildew pathogens of maize}

Among the various maize diseases, downy mildews are considered to be the major diseases. In origin, the downy mildews are "old world" diseases that now are very damaging and prevalent on the "new world crop" - maize (Shaw, 1975). None of the downy mildew diseases originated on maize (Shaw, 1975) but they possessed the ability to attack maize when maize was introduced from the new world to old world. Heavy losses (as high as 100 per cent) in maize due to downy mildew pathogens have been recorded in Philippines, Taiwan, Indonesia, Thailand, India, West Africa, Venezuela, Japan, Australia, Europe, North America and other parts of the world (Bonde, 1982 and Rifin, 1983). Twenty one species of downy mildew pathogens have been reported to attack the graminae family (Shaw, 1975). Of these, ten species of fungi belong to three genera (seven species of Peronosclerospora, one species of Sclerospora and two species of Sclerophthora) have been reported to cause different types of downy mildews in maize 
(Frederiksen and Renfro, 1977; Siradhana et al., 1980 and Rathore et al., 2002). The details are given in Table 1 .

Downy mildews such as Sorghum downy mildew, Philippine downy mildew, Sugar cane downy mildew, Brown stripe downy mildew and more recently identified Rajasthan downy mildew were reported from different agroecological regions in India (Payak, 1975a; Siradhana et al., 1980). Sorghum Downy Mildew (SDM) is particularly prevalent in the Peninsular India, in the states of Karnataka, Tamil Nadu and Andhra Pradesh reportedly causing yield losses of 30 per cent and higher (Payak, 1975a, 1975b and Krishnappa et al., 1995). SDM became an internationally important disease of maize during the years of rapid expansion of the use of sorghum for grain and forage (Sabry et al., 2006; Lukman et al., 2013; Muis et al., 2015).

It infects both maize and sorghum in warm and humid areas of the world (Frederiksen, 1980). The pathogen infects the roots primarily by oospores and the leaves by conidia and reaches the meristem causing systemic infection. Systemically infected plants do not produce cobs. If at all produce cobs they have only a few seeds and it causes severe yield loss in maize. It is an obligate parasite (Cardwell et al., 1997) that cannot be cultured in the laboratory. The disease occurs in both maize and sorghum in warm and humid areas of the world (Sabry et al., 2006).

\section{Taxonomy of $P$. sorghi}

SDM has two crop hosts, sorghum and maize. It is a member of subdivision Mastigomycotina, class Oomycetes, order Peronosporales and family Peronosporaceae. The widely prevalent SDM was first reported by Butler (1907) in Tamil Nadu and Maharastra states of India. He considered it to be Sclerospora graminicola at that time.
Subsequently, Kulkarni (1913) in India observed that, in the asexual phase, germination was direct by means of a germ tube from conidia (rather than through zoospores from sporangia) and primarily on the basis he recommended designation of varietal rank as Sclerospora graminicola var Andropogonis-sorghi. Weston and Uppal (1932) described this fungus in English and further investigation of morphology and host range he named it as Sclerospora sorghi in 1932. In 1978 C.G. Shaw proposed the new genus Peronosclerospora as subgenus of Sclerospora based on conidial germination (by a germ tube) and he transferred genus name from Sclerospora in to Peronosclerospora that produce conidia which germinate directly by a germ tube (Shaw, 1978). From 1978 this SDM pathogen has been named as Peronosclerospora sorghi [(Weston and Uppal) C.G. Shaw].

\section{Symptoms of sorghum downy mildew on maize}

Systemic infection in maize seedlings is characterized by chlorosis which normally appears two weeks after sowing (Safeeulla, 1974). The leaves of infected plants tend to be narrower and more erect than those of healthy plants. Plants infected early usually die approximately four weeks after infection (Ajala et al., 2003). In late infected plants, the chlorosis may be more noticeable on the lower half of the leaf which is often called half-leaf symptom. This chlorosis gradually covers the entire leaf surface at later stage (Safeeulla, 1974). Under warm humid conditions, a white downy growth is produced on the lower leaf surface some times on both surfaces also. This growth is a combination of conidia and conidiophores (Jeger et al., 1998). In maize, leaf shredding is rare but it is common in sorghum (Jeger et al., 1998). At flowering stage of growth, infected plants produced a bushy top, referred to a crazy top in place of 
the tassel. Systemically infected maize plants generally do not form cob. In some cases when cobs formed, these are small and poorly filled (Ajala et al., 2003).

\section{Sorghum downy mildew - pathogen variability}

Variability for pathogenicity in $P$. sorghi increases the potential for damage from SDM. Breeders should attempt to diversify their sources of DM resistance as quickly as possible to reduce the vulnerability of corn (Craig and Frederiksen, 1980). The first report of pathogenic variability of $P$. sorghi was found on sorghum crop from the USA in the late 1970s when a previously resistant and popular sorghum hybrid was infected with SDM (Craig and Frederiksen, 1980). Three distinct pathotypes were identified on sorghum in the USA from the differential reaction of the inbred lines Tx412, Tx430, CS3541 and QL-3 (Craig and Frederiksen, 1983) and their mode of inheritance of resistance was determined by Craig and Schertz (1985) and Sifuentes and Frederiksen (1988). Pawar et al., (1985) screened 75 sorghum varieties against sixteen isolates of $P$. sorghi from different geographic regions and found that a differential reaction identified in each isolate as a different pathotype. Bock et al., (2000) sampled nine isolates of $P$. sorghi from maize, sorghum and wild sorghum in Southern and Eastern Africa and they were compared for pathogenicity on different sorghum and maize cultivars which provided evidence for the existence of pathogenic variability among geographically distant populations of $P$. sorghi in Africa (Bock and Jeger, 2002). The isolates from Africa and Asia were more pathogenic than those from Americas (Jeger et al., 1998).

Although $P$. sorghi typically infects both sorghum and maize (the sorghum strain), there are reports of strains that infect only maize (the maize strain) (Bock et al., 2000). Payak (1975b) postulated that three races of the pathogen viz., sorghum, sorghum-maize and maize races differentiated by pathogenicity to sorghum and maize, occurred in India. The form of $P$. sorghi found in Rajasthan, India, is pathogenic to maize and Heterpogan contortus (L.) Beauv. but not to sorghum (Dange, 1976; Frederiksen and Renfro, 1977; Kothari et al., 1980 and Siradhana et al., 1980). In contrast, $P$. sorghi in Southern India (the states of Karnataka, Tamil Nadu and Andhra Pradesh) attacks maize and sorghum but not H. contortus (Payak, 1975b; Safeeulla, 1976 and Frederiksen and Renfro, 1977). The downy mildew prevalent in the Udaipur district of Rajasthan State in India, with $H$. contortus as the collateral host has been recently designated as 'Rajasthan downy mildew' (Siradhana et al., 1980) caused by $P$. heteropogoni. Earlier, this pathogen was considered as a variant of $P$. sorghi (Nair et al., 2004).

\section{Epidemiology of sorghum downy mildew}

A good knowledge of the disease epidemiology is required to design an effective screening method and also to recommend a control measures. $P$. sorghi has both a sexual and an asexual phase (Jeger et al., 1998). During the sexual phase oospores are formed which enable the pathogen to survive the long, hot, dry and crop free periods (Williams, 1984). The asexual phase occurs in periods characterized by moderate temperature and high relative humidity (Lal, 1981). The primary sources of infection are oospores capable of surviving several seasons in the soil even up to ten years (Williams, 1984 and Bonde, 2008). Oospores germinate by germ tubes (Safeeulla, 1976 and Pratt, 1978) in the presence of host (Pratt, 1978) and infect underground parts of the plant. No germination was observed in the absence of plant roots (Pratt, 1978). Schuh et al., (1987a) 
determined the optimum soil condition for incidence of SDM on sorghum. A soil temperature- soil moisture combination of $25^{\circ} \mathrm{C}$ and -0.2 bar and a soil texture-inoculum density combination of 80 per cent sand content and 5 gram of oospore power per 100 gram of soil gave the highest disease incidence. Saturated soils and dry soil were both suppressive for disease (Balasubramanian, 1974). This was substantiated by a Principal Component Analysis of weather data (Schuh et al., 1987b). The number of oospores dispersed increased exponentially with increasing wind speed (Bock et al., 1997). Leaf shredding and oospore production were comparatively higher on sorghum than on maize (Bigirwa et al., 1998). Infection by oospores results in systemically infected plants (Schuh et al., 1988).

In the case of asexual phase conidia are produced between 15 and $23^{\circ} \mathrm{C}$ (Bonde et al., 1985) through the stoma (Lal, 1981) In India, conidia of $P$. sorghi are produced between midnight and 5.00 AM when temperature are about $20^{\circ} \mathrm{C}$ and relative humidity greater than 85 per cent (Shenoi and Ramalingam, 1979 and Bock et al., 1998). After conidial production and dispersal, germination occurs through one or more germ tubes and subsequent penetration occurs within a few hours (Bonde, 1982). Mature conidia begin to germinate within one hour after dislodging from conidiophore (Craig, 1987 and Cardwell et al., 1994). Germination and germ tube growth took place in the conidial temperature range of 10 to $34^{\circ} \mathrm{C}$ (Bock et al., 1999) and it declined with the increase in temperature (Bonde et al., 1978 and Rao et al., 1987). Conidia germinate by a germ tube (Lal, 1981) under saturated air (Lal, 1981; Bonde et al., 1978 and Bonde, 1982).

In India, the optimum temperature range for conidial germination was reported to be 21 to $25^{\circ} \mathrm{C}$ (Safeeulla et al., 1974). Plant age affects the incidence of infection. Maize plants older than 15 days were resistant to systemic infection by conidia (Bock et al., 1999; Yeh and Frederiksen, 1980 and Siradhana et al., 1978b). Normally conidiophores arise through stomata and these conidiophores are stout, dichotomously branched and terminating in sterigmata and conidia borne on their tips. Conidia are hyaline, thin walled and they detach easily from conidiophores (Lal, 1981) and enter into air. A very low wind speed is sufficient to disperse conidia (Bock et al., 1998) and this forms secondary infection in maize field. Generally, crop escaped infection when the sowing was done before or on the onset of monsoon (Siradhana et al., 1975 and 1978a). $P$. sorghi may be transmitted internally in maize seed either as mycelium (Jones et al., 1972, Safeeulla and Shetty, 1977, Rao et al., 1985, and Adenle and Cardwell, 2000) or as oospores (Rao et al., 1984). Seed transmission appeared to only occur with freshly harvested seed or immature seeds (Jones et al., 1972).

\section{Sorghum Downy Mildew - Screening methods}

SDM is one of the destructive diseases and has the capacity for epiphytotics on susceptible genotypes under favorable conditions in the epidemic areas of Karnataka, Maharashtra, Andhra Pradesh and Tamil Nadu states in India (Sundaram, 1977 and Anahosur, 1978). Breeding resistant varieties is one of the effective and cheap methods to control this disease. In any breeding programme for disease resistance, the first step is to screen all available materials against disease pathogen. A sound screening technique forms the basis of identification of sources of resistance for disease resistance breeding programme (Anahosur and Hegde, 1979). It is also necessary to investigate the inheritance and genetics of resistance (Jeger et al., 1998). 
Screening for resistance to the SDM has been carried out in the field (Anahosur and Hegde (1979), Cardwell et al., 1997, Setty et al., 2001, George et al., 2003, Yen et al., 2004, Nair et al., 2004 and Nair et al., 2005) and in the green house (Jones, 1970, Schmitt and Freytag, 1974, Craig, 1976, and Narayana et al., 1995).

\section{Field screening}

Anahosur and Hegde (1979) compared the five different techniques for screening sorghum genotypes against SDM in the field and revealed that 'Infector row' planting was the most reliable technique for assured screening. In this technique, oospore inoculum was incorporated into the furrows and the highly susceptible genotype was sown two weeks early. In continuation to these infector rows, the test lines were sown where the oospore inoculum was previously incorporated. So the test lines were exposed to both oospores from soil and conidia from infector rows thus minimizing escapes.

Cardwell et al., (1997) have developed 'Direct seed inoculation' method for screening maize genotypes against SDM. They followed the same steps as in the case of infector row technique. But the difference is they used conidial infected pre-germinated seeds for infector row sowing instead of direct sowing. By adopting this technique they obtained consistent and high incidence of downy mildew infected plants. This method required substantially less labour and inoculum than the spray inoculation of spreader row. In this method planting of the pre-germinated seeds required more care than planting unimbibed seed. So planting of the spreader rows is slightly slower in this direct seed inoculation method.

Disease nurseries planted in sick plot where SDM is endemic have been widely used.
Several such SDM sick plots are maintained in South Texas by Commercial seed companies as well as by the Texas Agricultural Experiment Station (Frederiksen, 1980). In India, SDM nursery has been maintained at the University of Agricultural Sciences Regional Research Station (UAS-RRS), Mandya in Karnataka state (Setty et al., 2001, George et al., 2003, Yen et al., 2004, Nair et al., 2004 and 2005). It is considered to be the National Centre for investigations on maize downy mildew in India (Krishnappa et al., 1995). However, use of these nurseries is limited to the growing season and the erratic occurrence of the disease requires repeated test to ensure reliable identification of resistant lines (Craig, 1980). To overcome such difficulty glass house techniques should be developed. So that maize genotypes can be screened throughout the year.

\section{Glasshouse screening}

Craig (1976) has developed seedling inoculation technique in which the maize seedlings were inoculated with conidia of $P$. sorghi in green house when the second leaf of the plant had unrolled enough for the leaf tip to flatten. A classification system was devised for leaf reactions based on the systems exhibited by the second leaf seven days after inoculation as resistant, intermediate and susceptible (Craig, 1982a). Many research workers have reported corn to be more susceptible to conidia than to oospores of $P$. sorghi (Frederiksen and Renfro, 1977; Frederiksen and Ullstrup, 1975; Kenneth and Shahor, 1973 and Saffeulla, 1976). So, conidial inoculation (Craig, 1976) of corn plants in the green house is a quick and relatively inexpensive method of screening for resistance to SDM. Craig (1980) noted that corn plants become less susceptible to conidial inoculum with increased age. This suggested that conidial inoculum at early stage of plant growth would be more efficient. 
Narayana and his coworkers (1995) compared six inoculation techniques for artificial promotion of SDM in green house for screening sorghum genotypes. Among the six inoculation method evaluated in the green house they obtained maximum downy mildew incidence of 100 percent when seedlings at the first leaf stage were spray-inoculated. This system is generally used under a controlled environment. Seedlings of the test materials are spray inoculated with a suspension of mature conidia. The advantage of this system is that optimal conditions can be maintained and the amount of inoculum is regulated. It can also provide a rapid technique for screening large quantities of materials in short time. Schmitt and Freytag (1974) also reported that conidial spray inoculation at seedling stage was most efficient in inducing severe downy mildew infection in corn and sorghum. No reliable method has been devised for green house tests of resistance with oospore inoculum (Craig, 1980).

For comparing host reactions it is necessary to develop an accurate and precise assessment method. Normally disease assessment has been carried out as per standard procedure given by Lal and Singh (1984) worldwide in case of systemic downy mildew diseases by recording the per cent downy mildew diseased plants. Based on per cent downy mildew incidence, a rating scale has been developed as $0-10$ per cent: resistant $(\mathrm{R}) ;>10-30$ per cent: moderately resistant (MR); >30 - 50 per cent: moderately susceptible (MS); $>50$ per cent: susceptible (S) (Yen et al., 2004, Nair et al., 2004 and 2005).

\section{Genetics of resistance to Sorghum Downy Mildew}

Although effective chemical measures (Anahosur and Patil, 1980; Odvody and Frederiksen, 1984a and 1984b; Anaso et al., 1989 and Sharma and Lal, 1998) are available for SDM, breeding resistant varieties and their cultivation has been a widely accepted phenomena in most of the crop improvement programmes (Shivanna and Anahosure, 1990). Genetic information relating to host resistance would provide more relevant basis for making breeding decisions. Considerable data have been reported concerning sources of resistance (Craig et al., 1977; Schmitt et al., 1977; Lima et al., 1982; De Leon et al., 1993; Setty et al., 2001; Ajala et al., 2003 and Yen et al., 2004). Information on the mode of inheritance of resistance to downy mildew, however, is limited in maize.

\section{Combining ability and gene action for resistance to Sorghum Downy Mildew}

Effective breeding methods for producing downy mildew resistant inbreds and hybrids would depend primarily on the mode of inheritance of resistance or susceptibility to the disease (Nair et al., 2004). In countries where downy mildews are a major constraint to maize production, independent research programmes had been initiated to determine the genetic basis of resistance to the prevalent downy mildews only within their respective germplasms. Sudha et al., (2004) identified NAI116 maize inbred having resistance both against Sorghum Downy Mildew and Rajasthan Downy mildew. In reports of genetic interpretation of resistance, there seems to be considerable variation according to the germplasm studied in various maize growing areas (Raymundo, 2000). Bockhold and Frederiksen (1972) and Frederiksen et al., (1973) investigated the inheritance of resistance to SDM in two diallel sets of inbred maize lines in the USA. Resistance was either fully or partially dominant, depending on the particular parents involved although in one parental line which carried an additional gene, susceptibility was dominant. They concluded that two or possible three genes control the reaction to SDM. 
Table.1 Pathogens causing downy mildew in maize

\begin{tabular}{|c|c|c|c|}
\hline Sl. No. & Common name & Scientific name & Geographic distribution \\
\hline 1. & Java DM & Peronosclerospora maydis & Indonesia \\
\hline 2. & Leaf splitting DM & P. miscanthi & Philippines, Taiwan \\
\hline 3. & Philippine DM & P. philippine & $\begin{array}{l}\begin{array}{l}\text { India, Indonesia, } \\
\text { Philippines, Thailand }\end{array} \\
\end{array}$ \\
\hline 4. & Sugar cane DM & P. sacchari & $\begin{array}{l}\text { Australia, Fiji Islands, India, } \\
\text { Japan, Nepal, New Guinea, } \\
\text { Philippines, Taiwan, Thailand }\end{array}$ \\
\hline 5. & Sorghum DM & P. sorghi & $\begin{array}{l}\text { Asia, Central America, Europe, } \\
\text { North America, South America, } \\
\text { Africa }\end{array}$ \\
\hline 6. & Spontaneum DM & P. spontaneae & Philippines \\
\hline 7. & Rajasthan DM & P. heteropogoni & Rajasthan (India) \\
\hline 8. & Green ear DM & Sclerospora graminicola & World wide \\
\hline 9. & Crazy top & Sclerophthora macrospora & World wide \\
\hline 10. & Brown strip DM & S. rayssiae var zeae & $\begin{array}{l}\text { India, Nepal, Pakistan, Sikkim, } \\
\text { Tailand }\end{array}$ \\
\hline
\end{tabular}

Jinahyon (1973) reported that the resistance to SDM was a quantitative character indicating polygenic inheritance. Frederiksen and Ullstrup (1975) studied the resistance to SDM and indicated that resistance was dominant in some crosses and recessive in others.

Schmitt et al., (1977) screened maize hybrids both in green house and in field and they compared their response to green house and field and suggested that resistance to conidial and oospore infection was under similar genetic systems.

Singburaudom and Renfro (1982) in a diallel crosses of ten maize inbred lines, found that susceptibility to $P$. sorghi was expressed as a dominant character. Few crosses showed intermediate levels of resistance. Their results indicated that resistance was controlled by many genes and that both additive and nonadditive gene effects were present. Genetic analysis of host resistance to SDM in India has proven that resistance to $P$. sorghi is under polygenic control.
Borges (1987) in a diallel cross of six maize inbred lines including reciprocals found intermediate disease reaction for the crosses between the resistant and susceptible lines. Their findings suggested a polygenic system for resistance to SDM in maize and additivity was clearly more important in determining disease reaction. They also found maternal inheritance for reaction to $P$. sorghi. However cytoplasmic inheritance was not detected in sorghum for resistance to SDM (Sifuentes and Frederiksen, 1988).

Predominance of additive gene action was concluded by Muthiah (1989), Geetha (1997) and Premlatha (2004) in the inheritance of resistance to SDM in maize. Additive effects are the predominant contributors to resistance (Nair et al., 2004). In addition, the recent observations that genotypes resistant to SDM are invariably resistant to Rajasthan downy mildew ( $P$. heteropogoni), while the Rajasthan downy mildew resistant genotypes might show differential response to SDM (Nair et al., 2004 and Yen et al., 2004). 


\section{Inheritance of resistance to Sorghum Downy Mildew}

Breeders should attempt to diversify their sources of SDM resistance as quickly as possible to reduce the vulnerability of maize (Craig and Frederiksen, 1980). Knowledge of the mode of inheritance of SDM resistance is necessary in choosing breeding populations (Singburaudom and Renfro, 1982). Studies on the inheritance of resistance provided information on the number of genetic factors involved in resistance to SDM. The identification of different genes for resistance is needed for development of cultivars with durable resistance to SDM (Sifuentes and Frederiksen, 1988). Most of the inheritance studies for resistance to SDM in maize have used generation mean analysis. It is popular method of analysis for quantitative characters.

Singburdom and Renfro (1982) obtained intermediate levels of resistance in crosses between resistance and susceptible to SDM and indicated that several genes were involved and that their effects were additive. Progenies of crosses between resistance lines were more resistant than their parents, probably because of interaction between different resistance genes (epistasis). They indicated that the reactions of maize to SDM were governed by several genes (polygenically) and that the inheritance of resistance was complex. Craig (1982b) studied the inheritance of resistance to SDM in maize using $F_{1}, F_{2}$ and backcross progenies and indicated that susceptibility was partially dominant and that resistance to $P$. sorghi was conditioned by two linked genes. Dominance type of gene effect was significant for resistance to SDM in maize suggested the importance of dominance in the control of SDM. Nevertheless in two crosses additive gene effect was also significant in addition to dominant gene effect (Krishnappa et al., 1995). Susceptibility to SDM infection was found to be partially dominant over resistance and resistance to SDM controlled by polygenes (Yen and Prasanna, 2001 and Yen et al., 2001) where as in sorghum resistance to SDM was found to be dominant (Reddy et al., 1992). No attempt has been reported in maize regarding number of genes involved for resistance to SDM using a chi-square test so far. However, reports are available in sorghum.

Studies (Rana et al., 1982) suggest that in sorghum there were three genes with major effects influencing SDM resistance in the parental material. When 296 was involved in crossing, only two of the three genes segregated giving a 15: 1 duplicate dihybrid $F_{2}$ ratio; when 303 was involved, a 57: $7 F_{2}$ ratio was obtained indicating that two of the genes segregated in a 9: 7 ratio and the third gene in a 3:1 ratio. Hence, SDM resistance in the crosses studied was controlled genetically by three pairs of genes with both complementary and duplicatory types of interaction involved in their genetics.

Craig and Schertz (1985) used $F_{1}, F_{2}$ and $F_{3}$ generations of the cross of sorghum between resistant line (QL-3) and universally susceptible line $(\mathrm{Tx} 412)$ to determine inheritance of resistance to $P$. sorghi. They obtained the $F_{2}$ phenotypic ratio as 3 resistant: 1 susceptible and its genotypic ratio as one homozygous resistant: 2 heterozygous: 1 homozygous susceptible using $\mathrm{F}_{3}$ phenotypes. Based on the reactions of the $F_{2}$ population they indicated that resistance to each pathotype (1,2 and 3) of $P$. sorghi was conditioned by a single dominant genetic factor.

The relationship between the genes for resistance to $P$. sorghi pathotypes 1,2, and 3 in the sorghum lines QL3-India and SC41412 were investigated by Sifuentes and Frederiksen (1988) with reciprocal crosses 
between them and susceptible lines. The results supported the hypothesis that QL3India has two genes conditioning resistance to each of the three pathotypes. Whereas SC41412 has one gene for resistance to the same three pathotypes.

Since the observed segregation in the $F_{2}$ of the cross between the resistant parents was in a agreement with a 63: 1 ratio, there appeared to be no linkage between these genes.

A further study by Reddy et al., (1992) also found resistance in QL-3 was dominant over susceptibility; a two-locus model with independent segregation and a combination of complementary and inhibitory interallelic interaction explained the inheritance pattern they observed. However, most resistance in sorghum is presumed to be monogenic, some possibly oligogenic, which implies a threat of resistance breaking down (Craig and Odvody, 1992).

The inheritance and mechanisms of resistance remain poorly understood and further work is needed to characterize these aspects of resistance in maize.

\section{Molecular marker analysis for resistance to Sorghum Downy Mildew}

Progress made in mapping agriculturally important genes with molecular markers forms the foundation for marker-aided selection (MAS). The use of MAS can expedite such difficult screening procedures such as the test for disease resistance. However when several resistance genes are initially present in a donor parent, some of them may be lost during the breeding programs. The chance of losing resistance genes can be reduced if they are detected early (Agrama et al., 1999). The mapping of quantitative trait loci (QTLs) makes feasible the detection, location and characterization of genetic factors contributing to the variation of polygenically inherited traits (Young, 1996).

The QTL mapping analysis for SDM resistance in Egyptian maize germplasm (Agrama et al., 1999) using single-factor analysis revealed three QTLs on two chromosomes (Chromosome 1 and 9) cumulatively explaining 53.6 per cent of the phenotypic variance. All three QTLs were contributed by the resistant parent G62 and have an additive gene action. Agrama et al., (2002) applied a combination of AFLP (Amplified Fragment Length Polymorphism) technique with bulked segregant analysis (BSA) to map the genes involved in the resistance to SDM in a recombinant inbred population.

Under the Asian Maize Biotechnology Network (AMBIONET) facilitated by CIMMYT (International maize and wheat Improvement Center), Mexico, the Indian team in collaboration with partners in Indonesia, Philippines and Thailand has carried out a study on QTL mapping of resistance against diverse DMs in the Asian region, including SDM (George et al., 2003). The study, utilizing recombinant inbred lines (RILs) derived from Ki3 (resistant) and CML139 (susceptible) led to the identification of five QTLs with significant effects on resistance to the five important DM diseases in Asia. Most significantly, a QTL on chromosome 6 at bin 6.05 was found to confer resistance to all five DM pathogens studied. Nair et al., (2001 and 2005) identified SDM resistance loci on maize Chromosomes 2, 3 and 6 in the Indian maize line NAI116 and verified that the locus on chromosome 6 also contributed resistance to diverse downy mildews.

Sabry et al., (2006) identified three QTLs appeared to have additive effects on resistance, identifying one major gene on 
chromosome 2 and two minor genes on chromosome 3 and 9 that contributed to downy mildew resistance. Identification of simple and accurately scored molecular markers for genes that contribute to downy mildew resistance of maize could greatly benefit future efforts to prevent disease losses.

Maize is mainly utilized for direct human consumption in developing countries and for livestock feed in developed countries. However, in recent years its utilization for diversified value-added products has made it an important crop. Corn probably yields more industrial products than any other cereal crops. Sorghum downy mildew (SDM) of maize caused by Peronosclerospora sorghi is a disease of great destructive potential because systemically infected plants seldom produce an ear. Breeding resistant varieties is one of the effective and cheap methods to control this disease. Genetic information relating to host resistance would provide more relevant basis for making breeding decisions. In maze, polygenic inheritance is observed for reaction against SDM infection. However, the inheritance and mechanism of resistance in maize are to be studied further in detail.

\section{References}

Adenle, V.O. and Cardwell, K.F. 2000. Seed transmission of maize downy mildew (Peronosclerospora sorghi) in Nigeria. Plant Pathology, 49(5): 628-634.

Agrama, H.A., M.E. Moussa, M.E. Naser, M.A. Tarek and Ibrahim, A.H. 1999. Mapping of QTL for downy mildew resistance in maize. Theor. Appl. Genet., 99: 519-523.

Agrama, H.A., S.F. Houssin and Tarek, M.A. 2002. Cloning of AFLP markers linked to resistance to Peronosclerospora sorghi in maize. Mol. Genet. Genomics, 267: 814-819.

Agricultural Statistics at a Glance, 2014, Directorate of Economics and Statistics,
Ministry of Agriculture, Govt. of India (Website: http: //www.dacnet.nic.in/ eands).

Ajala, S.O., J.G. Kling, S.K. Kim and Obajimi, A.O. 2003. Improvement of maize populations for resistance to downy mildew. Plant Breed., 122: 328333.

Anahosur, K.H. 1978. Current sorghum downy mildew research in the all India sorghum project. Paper presented at the International workshop on sorghum diseases at ICRISAT, Hyderabad. pp: 15.

Anahosur, K.H. and Hegde, R.K. 1979. Assessment of the techniques used for screening sorghum genotypes to downy mildew. Mysore J. Agric. Sci., 13(4): 449-451.

Anahosur, K.H. and Patil, S.H. 1980. Chemical control of sorghum downy mildew in India. Plant Dis., 64(11): 1004-1006.

Anaso, A.B., P.D. Tyagi, A.M. Emechebe and Manzo, S.K. 1989. Control of sorghum downy mildew (Peronosclerospora sorghi) of maize by seed treatment in Nigeria. Crop Protection, 8(2): 82-85.

Balasubramanian, K.A. 1974. Role of date of seeding, soil moisture, temperature and $\mathrm{pH}$ in the incidence of downy mildew of sorghum. Plant and Soil, 41: 233-241.

Bigirwa, G., E. Adipala and Esele, J.P. 1998. Occurrence of Peronosclerospora sorghi in Uganda. Plant Dis., 82(7): 757-760.

Bock, C. H., M. J. Jeger, B.D.L. Fitt and Sherington, J.1997. Effect of wind on the dispersal of oospores of Peronosclerospora sorghi from sorghum. Plant Pathology, 46: 439-449.

Bock, C. H., M. J. Jeger, L. K. Mughogho, K. F. Cardwell and Mtisi, E.1999. Effect of dew point temperature and conidium age on germination, germ tube growth and infection of maize and sorghum by 
Peronosclerospora sorghi. Mycol. Res., 103 (7): 859-864.

Bock, C. H., M. J. Jeger, L. K. Mughogho, K. F. Cardwell, E. Mtisi, G. Kaula and Mukansabimana, D.2000. Variability of Peronosclerospora sorghi isolates from different geographic locations and hosts in Africa. Mycol. Res., 104 (1): 61-68

Bock, C.H. and Jeger, M.J. 2002. The distribution and spread of sorghum downy mildew in sorghum and maize fields in Nigeria and Zimbabwe. European Journal of Plant Pathology, 108 (8): 745-753.

Bock, C.H., M.J. Jeger, L.K. Mughogho, E. Mtisi and Cardwell, K.F. 1998. Production of conidia by Peronosclerospora sorghi on sorghum crops in Zimbabwe. Plant Pathol., 47(3): 243-251.

Bockhold, A.J. and Frederiksen, R.A. 1972. Breeding corn for resistance to sorghum downy mildew. Agron. J., 64: 3.

Bonde, M.R. 1982. Epidemiology of downy mildew diseases of maize, sorghum and pearl millet. Trop. Pest Management, 28(1): 49-60.

Bonde, M.R. 2008. Epidemiology of downy mildew diseases of maize, sorghum and pearl millet. Tropical Pest Management, 28(1): 49-60.

Bonde, M.R., C.G. Schmitt and Dapper, R.W. 1978. Effects of dew-period temperature on germination of conidia and systemic infection of maize by Sclerospora sorghi. Phytopathol., 68: 219-222.

Bonde, M.R., G.L. Peterson and Duck, N.B. 1985. Effects of temperature on sporulation, conidial germination, and infecton of maize by Peronosclerospora sorghi from different geographical areas. Phytopathol., 75(1): 122-126.

Borges, O.L. 1987. Diallel analysis of maize resistance to sorghum downy mildew. Crop Sci., 27: 178-180.
Butler, E.J. 1907. Some diseases of cereals caused by Sclerospora graminicola. Mem. Dep. Agric. India Bot. Ser., 2: 124.

Cardwell, K.F., C. Bock, O.F. Akinnioye, D. Onukwa, V. Adenle and Adetoro, A.O. 1994. Improving screening methods for resistance to downy mildew of maize in Nigeria. Plant Health Manage. Res. Monogr., 22: 22-25.

Cardwell, K.F., J.G. Kling and Bock, C. 1997. Methods for screening maize against downy mildew Peronosclerospora sorghi. Plant Breed., 116(3): 221-226.

Craig, J. 1976. An inoculation technique for identifying resistance to sorghum downy mildew. Plant Dis. Reptr., 60: 350-352.

Craig, J. 1980. Comparative reactions of corn inbreds to oospore and conidial inoculum of Peronosclerospora sorghi. Phytopathology, 70(4): 313-315.

Craig, J. 1982a. Identification of sorghum downy mildew resistance in corn by leaf reaction to conidial inoculum. Phytopathology, 72: 351-352.

Craig, J. 1982b. Inheritance of resistance to sorghum downy mildew in corn. Phytopathology, 72(7): 943.

Craig, J. 1987. Tiered temperature system for producing and storing conidia of Peronosclerospora sorghi. Plant Dis., 71: 356-358.

Craig, J. and Frederiksen, R.A. 1980. Pathotypes of Peronosclerospora sorghi. Plant Dis., 64(8): 778-779.

Craig, J. and Frederiksen, R.A. 1983. Differential sporulation of pathotypes of Peronosclerospora sorghi on inoculated sorghum. Plant Dis., 67(3): 278-279.

Craig, J. and Odvody, G.N. 1992. Current status of sorghum downy mildew control. pp: 213-217. In W.A.J. de Milliano et al., (ed.) Sorghum and millets diseases: A second world 
review. AP 502324. ICRISAT, Patancheru, India.

Craig, J. and Schertz, K.F. 1985. Inheritance of resistance in sorghum to three pathotypes of Peronosclerospora sorghi. Phytopathology, 75(9): 10771078.

Craig, J., A.J. Bockholt, R.A. Frederiksen and Zuber, M.S. 1977. Reaction of important corn inbred lines to Sclerospora sorghi. Plant Dis. Reptr., 61(7): 563-564.

Dange, S.R.S. 1976. Sorghum downy mildew (Sclerospora sorghi) of maize in Rajasthan, India. Kasetsart J., 10: 121217.

De Leon, C., G. Granados, R.N. Wedderburn and Pandey, S. 1993. Simultaneous improvement of downy mildew resistance and agronomic traits in tropical maize. Crop Sci., 33: 100-102.

De Wet, J.M.J. and Harlan, J.R. 1972. Origin of maize: The tripartite hypothesis. Euphytica, 21: 271-279.

Department of Economics and Statistics, Chennai, 2014

Dhillon, B.S. 1998. Maize. In. Hybrid cultivar development. Ed. Banaga, S.S. and S.K. Banga. Naosa Publishing House. New Delhi, India.

Dowswell, C.R., R.L. Paliwal and Cantrell, R.P. 1996. Maize in the third world. Westview Press, Boulder, USA

FAO, 2012. World Wheat, Corn, and Rice Production, Food and Agricultural Organization, Italy.

Frederiksen, R.A. 1980. Sorghum downy mildew in the United States: overview and outlook. Plant Dis., 64(10): 903-908.

Frederiksen, R.A. and Renfro, B.L. 1977. Global status of maize downy mildew. Annu. Rev. Phytopathol., 15: 249-275.

Frederiksen, R.A. and Ullstrup, A.J. 1975. Sorghum downy mildew in the United States. Trop. Agric. Res., 8: 39-43.
Frederiksen, R.A., A.J. Bockholt, L.E. Clark, J.W. Cosper, J. Craig, J.W. Johnson, B.L. Jones, P. Matocha, F.R. Miller, L. Reyes, D.T. Rosenow, D. Tuleen and Walker, H.J. 1973. Sorghum downy mildew: A disease of maize and sorghum. Texas Agric. Exp. Stn. Res. Monogr., 2: 1-32.

Frederiksen, R.A., J. Amador, B.L. Jones and Reyes, L. 1969. Distribution, symptoms and economic loss from downy mildew caused by Sclerospora sorghi in grain sorghum in Texas. Plant Dis. Reptr., 53: 995-998.

Geetha, K. 1997. Genetic analysis of yield, starch and downy mildew resistance in maize (Zea mays L.) Ph.D. Thesis. Tamil Nadu Agricultural University, Coimbatore, India.

George, M.L.C., B.M. Prasanna, R.S. Rathore, T.A.S. Setty, F. Kasim, M. Azrai, S. Vasal, O. Balla, D. Hautea, A. Canama, E. Regalado, M. Vargas, M. Khairallah, D. Jeffers and Hoisington, D. 2003. Identification of QTLs conferring resistance to downy mildew of maize in Asia. Theor. Appl. Genet., 107: 544551.

Jeger, M.J., E. Gilijamse, C.H. Bock and Frinking, H.D. 1998. The epidemiology, variability and control of the downy mildews of pearl millet and sorghum, with particular reference to Africa. Plant Pathology, 47(5): 544-569.

Jinahyon, S. 1973. The genetics of resistance and its implications to breeding for resistance in corn. Proc. 9th Inter-Asian Corn Improv. Workshop, Malayia, pp: 3039.

Jones, B.L. 1970. A simple technique of inoculating sorghum with Sclerospora sorghi using conidia as inoculum. Plant Dis. Reptr., 54: 603-604.

Jones, B.L., J.C. Leeper and Frederiksen, R.A. 1972. Sclerospora sorghi in corn: its 
location in carpellate flowers and mature seeds. Phytopathology, 62: 817-819.

Kenneth, R. and Shahor, G. 1973. Systemic infection of sorghum and corn by conidia of Sclerospora sorghi. Phytoparasitica, 1(1): 13-21.

Kothari, K.L., K.L. Jain, R.S. Rathore and Singh, S.D. 1980. Occurrence of a new strain of sorghum downy mildew Peronosclerospora sorghi and its oospores on maize in Rajasthan. Current Sci., 49(10): 401-402.

Krishnappa, M., B.S. Naidu and Seetharam, A. 1995. Inheritance of resistance to downy mildew in maize. Crop Improv., 22(1): 33-37.

Kulkarni, G.S. 1913. Observations on the downy mildew (Sclerospora graminicola (Sacc.) Schroet) of bajra and jowar. Mem. Dep. Agric. India Bot. Ser., 5: 268-274.

Lal, S. 1981. Developmental stages in Peronosclerospora sorghi, the sorghum downy mildew of maize. Acta Bot. Indica, 9: 171-174.

Lal, S. and Singh, I.S. 1984. Breeding for resistance to downy mildews and stalk rots in maize. Theor. Appl. Genet., 69: 111-119.

Lima, M., N. Gimenes-Fernandes, J.B. Miranda Filho and Pereira, J.C.V.A. 1982. Introduction of maize germplasms as sources for downy mildew resistance. Maydica, 27: 159168.

Lukman, R., A. Afifuddin and Lubberstedt, T. 2013. Unraveling the genetic diversity of maize downy mildew in Indonesia. $J$. Plant Pathol. Microbiol. 4: 162.

Moore, C.L. and Renfro, B.L. 1971. Maize in the Asian region. Proc. $1^{\text {st }}$ Maize Workshop, pp: 37-41. Mexico City: CIMMYT.

Muis, A, N. Nonci and Pabendon, M. B. 2015. Genetic diversity of S3 maize genotypes resistant to downy mildew based on
SSR markers. Indonesian Journal of Agricultural Science, 16(2): 79-86.

Muthiah, AR. 1989. Genetic analysis and inheritance of sorghum downy mildew resistance in maize (Zea mays L.) Ph.D. Thesis, Tamil Nadu Agricultural University, Coimbatore, India.

Nair, S.K., B.M. Prasanna, A. Garg, R.S. Rathore, T.A.S. Setty and Singh, N.N. 2005. Identification and validation of QTLs conferring resistance to sorghum downy mildew (Peronosclerospora sorghi) and Rajasthan downy mildew (Peronosclerospora heteropogoni) in maize. Theor. Appl. Genet., 110: 13841392.

Nair, S.K., B.M. Prasanna, R.S. Rathore, T.A.S. Setty, R. Kumar and Singh, N.N. 2004. Genetic analysis of resistance to sorghum downy mildew and Rajasthan downy mildew in maize (Zea mays L.). Field Crop Research, 89: 379-387.

Nair, S.K., T.A. Setty, R.S. Rathore, R. Kumar, N.N. Singh and Prasanna, B.M. 2001. Towards molecular marker mapping of genes conferring resistance to sorghum downy mildew (Peronosclerospora sorghi) in maize. Maize Genetic Co-operation Newsletter, 75.

Narayana, Y.D., L.K. Mughogho and Bandyopadhyay, R. 1995. Evaluation of greenhouse inoculation techniques to screen sorghum for resistance to downy mildew. Euphytica, 86: 49-53.

Odvody, G.N. and Frederiksen, R.A. 1984a. Use of systemic fungicides metalaxyl and fosetyl-Al for control of sorghum downy mildew in corn and sorghum in South Texas. I: seed treatment. Plant Dis., 68(7): 604-607.

Odvody, G.N. and Frederiksen, R.A. 1984b. Use of systemic fungicides metalaxyl and fosetyl-Al for control of sorghum downy mildew in corn and sorghum in South 
Texas. II: foliar application. Plant Dis., 68(7): 608-609.

Pawar, M.N., R.A. Frederiksen, L.K. Mughogho and Bonde, M.R. 1985. Survey of virulence in Peronosclerospora sorghi isolates from India, Ethiopia, Nigeria, Texas (USA), Honduras, Brazil, and Argentina. Phytopathology, 75(11): 1374.

Payak, M. M. 1975a. Downy mildews of maize in India. Trop. Agric. Res. Series (Tokyo). 8: $13-18$.

Payak, M.M. 1975b. Epidemiology of downy mildews with special reference to those occurring in Asia. Trop. Agric. Res., 8: 81-91.

Pratt, R.G. 1978. Germination of oospores of Sclerospora sorghi in the presence of growing roots of host and non-host plants. Phytopathol., 68: 1606-1613.

Premalatha, N. 2004. Genetic analysis for downy mildew resistance, yield and its component traits in maize (Zea mays L.). Ph.D. Thesis, Tamil Nadu Agricultural University, Coimbatore, India.

Pupipat, U. 1975. Host range, geographic distribution and physiologic races of the maize downy mildews. Trop. Agric. Res., 8: 63-80.

Rana, B.S., K.H. Anahosur, M.J. Rao, V.J.M. Rao, R. Parameshwarappa and Rao, N.G.P. 1982. Inheritance of field resistance to sorghum downy mildew. Indian J. Genet., 42: 70-74.

Rao, B., M. Shetty, H. Shekara and Safeeulla, K.M. 1984. Production of Peronosclerospora sorghi oospores in maize seeds and further studies on the seed-borne nature of the fungus. Indian Phytopathol., 37(2): 278-283.

Rao, B.M., H.S. Prakash, H.S. Shetty and Safeeulla, K.M. 1985. Downy mildew inoculum in maize seeds: techniques to detect seed-borne inoculum of
Peronosclerospora sorghi in maize. Seed Science and Technology, 13(3): 593-600.

Rao,B.M., H.S. Shetty and Safeeulla, K.M. 1987. Effect of temperature on conidial germination and germ tube growth of different isolates of Peronosclerospora sorghi from maize. Indian Phytopathol., 40(3): 352-355.

Rathore, R.S. and Jain, M.L. 2000. Management of maize downy mildew through resistant varieties. Proceedings: Indian Phytopathological SocietyGolden Jubilee, International conference on Integrated Plant Disease Management for Sustainable Agriculture, pp: 160-161.

Rathore, R.S., A. Trivedi and Mathur, K. 2002. Rajasthan downy mildew of maize: The problem and management perspectives Proceeding of the $8^{\text {th }}$ Asian Regional Maize Workshop, Bangkok, Thailand: August 5-8.

Raymundo, A.D. 2000. Downy mildew of maize in Asia: new perspectives in resistance breeding. In: Vasal, S.K., Gonzalez Ceniceros F., Xingming, F. (eds) Proc. $7^{\text {th }}$ Asian Regional Maize Workshop. PCARRD, Los Banos, Philippines, pp: 277-284.

Reddy, B.V.S., L.K. Mughogho, Y.D. Narayana, K.D. Nicodemus and Stenhouse, J.W. 1992. Inheritance pattern of downy mildew resistance in advanced generations of sorghum. Ann. Appl. Biol., 121: 249-255.

Rifin, A. 1983. Downy mildew resistance of single cross progenies between Indonesian and Philippine corn inbred lines. Penelitian Pertanian, 3: 81-83.

Sabry, A., D. Jejjers, S.K. Vasal, R.A. Frederiksen and Magill, C. 2006. A region of maize chromosome 2 affects response to downy mildew pathogens. Theor. Appl. Genet., 113: 321-330.

Safeeulla, K.M. 1974. Infection of maize by downy mildews. Symposium on downy 
mildew of maize, Tokyo, Japan. Trop. Agric. Res. Series, 8: 93-102.

Safeeulla, K.M. 1976. Biology and control of the downy mildews of pearl millet, sorghum and finger millet. Wesley Press, Mysore, India. Pp: 304.

Safeeulla, K.M. and Shetty, H.S. 1977. Seed transmission of sorghum downy mildew in corn. Seeds and Farms, 3: 21-22.

Safeeulla, K.M., H.S. Shetty and Rao, N.G.P. 1974. Sorghum downy mildew. In Research Report, Department of PostGraduate Studies and Research in Botany. Manasagangothri, Mysore, India. 1973-1974. pp: 49.

Schmitt, C.G. and Freytag, R.E. 1974. A quantitative technique for inoculating corn and sorghum with conidia of Sclerospora sorghi. Plant Dis. Reptr., 58: 825-829.

Schmitt, C.G., G.E. Scott and Freytag, R.E. 1977. Response of maize diallel cross to Sclerospora sorghi, cause of sorghum downy mildew. Plant Dis. Reptr., 61(7): 607-608.

Schuh, W., M.J. Jeger and Frederiksen, R.A. 1987a. The influence of soil temperature, soil moisture, soil texture, and inoculum density on the incidence of sorghum downy mildew. Phytopathology, 77(2): 125-128.

Schuh, W., M.J. Jeger and Frederiksen, R.A. 1987b. The influence of soil environment on the incidence of sorghum downy mildew: a principal component analysis. Phytopathology, 77(2): 128-131.

Schuh, W., M.J. Jeger and Frederiksen, R.A. 1988. Comparisons of spatial patterns of oospores of Peronosclerospora sorghi in the soil and of sorghum plants with systemic downy mildew. Phytopathology, 78(4): 432-434.

Setty, S., G.R. Ramaswamy, K.T. Pandurangae Gowda, T.B. Anilkumar, T.A. Puttaramanaik and Srinivasachary. 2001. Reaction of some maize genotypes against sorghum downy mildew. Plant Dis. Res., 16(1): 127129.

Sharma, R.C. and Lal, S. 1998. Maize diseases and their management. Indian Farming, 48(1): 92-96.

Shaw, C.G. 1975. The taxonomy of graminicolous downy mildews with emphasis on those attacking maize. Trop. Agric. Res., 8: 47-55.

Shaw, C.G. 1978. Peronosclerospora species and other downy mildews of the gramineae. Mycologia, 70: 594-604.

Shivanna, H. and Anahosur, K.H. 1990. Breeding downy mildew resistant sorghum varieties. Indian Phytopath., 43(3): 372-374.

Shull, G.H. 1909. A pureline method of corn breeding. Am. Breed. Assoc. Rep., 5: 5159.

Sifuentes, J. and Frederiksen, R.A. 1988. Inheritance of resistance to pathotypes 1, 2 and 3 of Peronosclerospora sorghi in sorghum. Plant Dis., 72(4): 332-333.

Singburaudom, N. and Renfro, B.L. 1982. Heritability of resistance in maize to sorghum downy mildew (Peronosclerospora sorghi (Weston and Uppal) C.G. Shaw). Crop Protect., 1(3): 323-332.

Siradhana, B.S., S.R.S. Danga, R.S. Rathore and Jain, K.L. 1975. Conidial inoculation technique for evaluating maize germplasm against sorghum downy mildew (Sclerospora sorghi) of maize. Plant Dis. Reptr., 60: 603-605.

Siradhana, B.S., S.R.S. Dange, K.L. Jain and Rathore, R.S. 1978a. Incidence of sorghum downy mildew on maize in relation to planting dates, and weather factors. Madras agric. J., 65(4): 267-269.

Siradhana, B.S., S.R.S. Dange, R.S. Rathore and Singh, S.D. 1978b. Ontogenic predisposition of Zea mays to sorghum downy mildew. Plant Dis. Reptr., 62(5): $467-468$. 
Siradhana, B.S., S.R.S. Dange, R.S. Rathore and Singh, S.D. 1980. A new downy mildew on maize in Rajasthan, India. Current Sci., 49(8): 316-317.

Sudha, K.N., B.M. Prasanna, R.S. Rathore, T.A.S. Setty, R. Kumar and Singh, N.N. 2004. Genetic variability in the Indian maize germplasm for resistance to sorghum Downy Mildew (Peronosclerospora sorghi) and Rajasthan Downy Mildew (Peronosclerospora heteropogoni). Maydica, 49: 57-64.

Sundaram, N.V. 1977. Pathological research in India. Paper presented at the International Workshop. ICRISAT, Hyderabad. pp: 19.

The Hindu Survey of Indian Agriculture. 2000. Policy support essential. Section 1. pp: 1720.

Weston, W.H. Jr. and Uppal, B.N. 1932. The basis for Sclerospora sorghi as a species. Phytopathol., 22: 573-586.

Williams, R.J. 1984. Downy mildews of tropical cereals. Adv. Plant Pathol., 2: $1-103$

Yeh, Y. and Frederiksen, R.A. 1980. Sorghum downy mildew: biology of systemic infection by conidia and of a resistant response in sorghum. Phytopathology, 70: 372-376.

Yen, T.T.O. and Prasanna, B.M. 2001. Analysis of genetic polymorphism among downy mildew resistance and susceptible maize inbred lines using simple sequence repeat (SSR) markers. Maize Genetic Co-operation Newsletter, 75.

Yen, T.T.O., B.M. Prasanna, T.A.S. Setty and Rathore, R.S. 2004. Genetic variability for resistance to sorghum downy mildew (Peronosclerospora sorghi) and Rajasthan downy mildew (Peronosclerospora heteropogoni) in the tropical / sub-tropical Asian maize germplasm. Euphytica, 138: 23-31.

Yen, T.T.O., R.S. Rathore, T.A. Setty, R. Kumar, N.N. Singh, S.K. Vasal and Prasanna, B.M. 2001. Inheritance of resistance to sorghum downy mildew (Peronosclerospora sorghi) and Rajastan downy mildew (Peronosclerospora heteropogoni) in maize in India. Maize Genetic Cooperation Newsletter, 75.

Young, N.D. 1996. QTL mapping and quantitative disease resistance in plants. Annu. Rev. Phytopathol., 34: 479-501.

\section{How to cite this article:}

Arulselvi, S., B. Selvi and Pandiyan, M. 2018. Sorghum Downy Mildew of Maize - A Review. Int.J.Curr.Microbiol.App.Sci. 7(08): 1472-1488. doi: https://doi.org/10.20546/ijcmas.2018.708.168 